\title{
Artificial seagrass experiments in the Northeast Mediterranean
}

\section{Kuzeydoğu Akdeniz'de yapay deniz çayırı denemeleri}

\section{Özgür Yılmaz ${ }^{1 *}$ • Sinan Mavruk² • Gökhan Gökçe ${ }^{3}$}

\author{
${ }^{1}$ Çukurova University, Yumurtalık Vocational School, 01680, Adana, Turkey \\ 2 Çukurova University, Fisheries Faculty, 01330, Adana, Turkey Turkey \\ ${ }^{3}$ Çukurova University, Fisheries Faculty, 01330, Adana, Turkey Turkey \\ https://orcid.org/0000-0002-0596-2896 \\ (D) $h$ ttps://orcid.org/0000-0003-1958-0634 \\ iD https://orcid.org/0000-0003-1830-0733
}

How to cite this paper:

Yılmaz, Ö., Mavruk, S. \& Gökçe, G. (2021). Artificial seagrass experiments in the Northeast Mediterranean. Ege Journal of Fisheries and Aquatic Sciences, 38(3), 355-364. DOI: 10.12714/egejfas.38.3.12

Abstract: Seagrasses provide important nursery grounds, shelter and natural habitats for juvenile fish. In this study, we evaluated if artificially created seagrass areas can play the same role as the natural seagrass (NS) habitats. The study was carried out in three different stations on the coast of Yumurtalık, Adana, selected according to the seagrass areas. Artificial seagrass (AS) was made of polypropylene ribbon and fixed on the ground in the designated areas with a depth of $0.5 \mathrm{~m}$ on average. Sampling was carried out with a beach seine net once a week at stations between 28 April 2016 and 11 August 2016 . Sampled fish were identified to the lowest possible taxonomic level. Based on our results, the fish abundance and species richness of NS and AS habitats were not statistically different, whereas the both parameters were significantly lower in sandy (S) habitats $(p<0.001)$. Moreover, the species composition of NS and AS habitats was found to be similar each other, whereas the composition was significantly different in $S$ habitats. This study, conducted in the Northeast Mediterranean, shows that AS habitats effect the distribution of juvenile fish.

Keywords: Meadows, juvenile fish, recruitment, nursery, Levant Basin

Öz: Deniz çayırları yavru balıklar için barınak, stoğa katılma ve doğal yaşam alanları sağlar. Bu çalışmada, yapay olarak oluşturulmuş deniz çayırı alanlarının doğal deniz çayıı (NS) habitatlarıyla aynı rolü oynayıp oynayamayacağı değerlendirilmiştir. Çalışma Adana, Yumurtalık kıyısında deniz çayırı alanlarına göre seçilen üç farklı istasyonda gerçekleştirilmiştir. Yapay deniz çayırı (AS) polipropilen şeritten yapılmıştır ve belirlenen alanlarda ortalama 0,5 m derinliğe sahip zemine sabitlenmiștir. Önekleme 28 Nisan 2016 ile 11 Ağustos 2016 tarihleri arasında istasyonlarda haftada bir ığrıp ile gerçekleștirimiş̧ir. Örneklenen balıklar mümkün olan en düşük taksonomik seviyede tespit edilmiştir. Sonuçlarımıza göre, NS ve AS habitatlarının balık bolluğu ve tür zenginliği istatistiksel olarak farklı değildir. Fakat her iki parametre de kumlu (S) habitatlarda daha düşük bulunmuştur $(p<0,001)$. NS ve AS habitatlarının tür kompozisyonu birbirine benzerken, S habitatlarında önemli ölçüde farklı bulunmuştur. Kuzeydoğu Akdeniz'de yapılan bu çalışma, AS habitatlarının yavru balıkların dağıımını etkilediğini göstermektedir.

Anahtar kelimeler: Çayır, yavru balık, stoğa katılma, yuva, Levant Baseni

\section{INTRODUCTION}

Seagrasses are quite important for the coastal ecosystems as a source of natural habitat, shelter, oxygen and food (Gullstrom et al., 2008; Hemminga and Duarte, 2000; Tuya et al., 2014). Seagrass habitats can support high invertebrate abundance and richness and this provide important source of food for many fish species (Jenkins et al., 1997; Orth, 1992; Orth et al., 1984; Pihl et al., 2006). Moreover, they also play important role in decreasing the water movement and therefore stabilizing the sand, along with securing the quality of water and producing oxygen (Becker and Choresh, 2006). One of the most important functions of seagrasses is their role as a shelter for juvenile fish by protecting them from the other predators as they can hide in the leaves of seagrasses (Beck et al., 2001; Deegan et al., 2002; Mattila et al., 1999; Pollard, 1984; Spalding et al., 2003).

There are 66 known species of seagrasses throughout the world (Kuo and Den Hartog, 2007), five of which, Zostera marina, Zostera noltii, Cymodocea nodosa, Posidonia oceanica and Halophila stipulacea distribute in Turkish coasts
(Demirci and Karakan, 2006), including the northeastern coasts of Levant Basin (Aysel et al., 2006).

The total destruction or the decline of seagrasses cause failing of its ecosystem services and resulted with adverse impacts both economically and environmentally (Orth et al., 2006; Waycott et al., 2006). Coastal structures, industrialization, marine pollution, illegal trawling along coasts are the major threats damaging the seagrass habitats (Boudouresque et al., 1994; Meinesz et al., 1991). Hence, in order to protect seagrass habitats, conservation measures have been taken over the coasts of most of Mediterranean Countries (Protocol, 1995). Additionally, habitat rehabilitation studies are in progress in disrupted areas (Irving et al., 2010). In this context, creating AS can also simulate the positive impacts of seagrasses on aquatic life. For instance Lee and Low (1991) reported that in the areas of AS, fish family increased from 12 to 14 , fish species increased from 16 to 30 and created a habitat for fish. Similarly, Saad et al. (2011) identified 497 fish belonging to 17 fish families in the field AS 
in their study and reported that AS created an important nutrient-rich habitat for marine fish. Upston and Booth (2003) showed that there were no significant differences in species richness and diversity between AS and NS area in Botany Bay, New South Wales. Although many studies have been performed about the function of AS on fish settlement, there is no empirical evidence in the Northeast Mediterranean.

In this study, we investigate the impact of AS areas on the settlement of fish in a relatively undisturbed coastal area in Northeast Mediterranean. For this purpose, we compared the species richness, composition, and total fish abundance between the S habitats, NS and AS habitats over the course of a four-month period when NS were available.

\section{MATERIALS AND METHODS}

The study was conducted in İskenderun Bay, along the coast of Yumurtalık (35040'50"E ile 36 $50^{\circ} 40^{\prime \prime N}$ ) (Figure 1). The average depth of a large part of Yumurtalık Bay is 2.8 meters, which is quite shallow (Avşar et al., 1999). The study area was built 20 meters away from the shore, on a seabed at an average depth of 0.5 meters. The site was safe from the impacts of currents, waves and wind effect and away from sites and human activities. The stations were arranged taking seagrasses into consideration as can be seen below (Table 1, Figure 1).

Table 1. Habitats at stations in the study

\begin{tabular}{llll}
\hline & Station 1 (S1) & Station 2 (S2) & Station 3 (S3) \\
\hline NS & $100 \mathrm{~m}^{2}$ & - & $100 \mathrm{~m}^{2}$ \\
AS & - & $25 \mathrm{~m}^{2}$ & $100 \mathrm{~m}^{2}$ \\
$\mathrm{~S}$ & $100 \mathrm{~m}^{2}$ & $25 \mathrm{~m}^{2}$ & $100 \mathrm{~m}^{2}$ \\
\hline
\end{tabular}

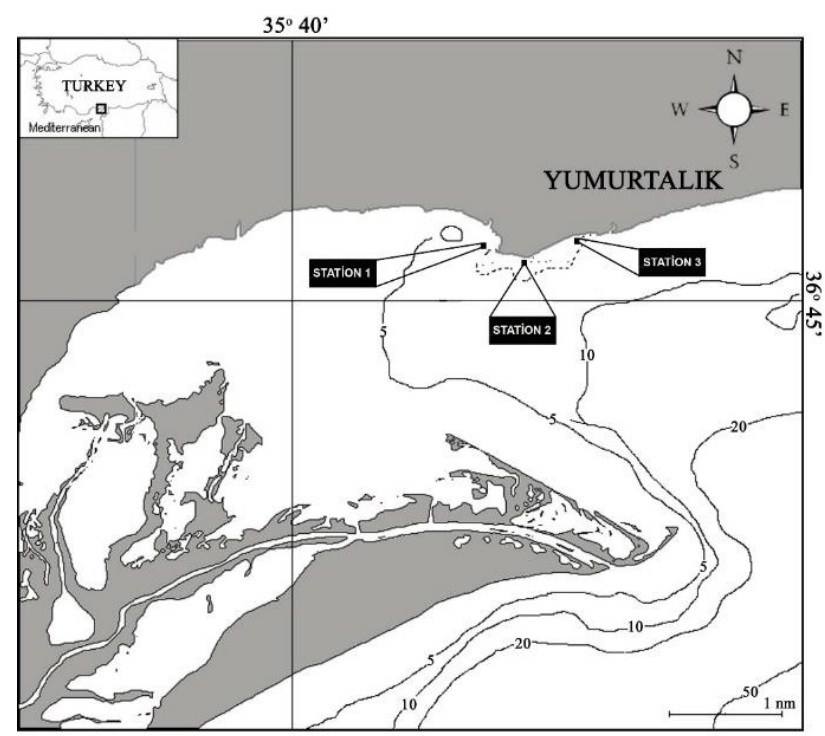

Figure 1. The locations of the stations on the map
Green thine polypropylene ribbon $\left(d=0.946 \mathrm{gr} / \mathrm{cm}^{3}\right)$ was used in the making of AS leaf. The ribbons were attached a wire mesh fence. The fence was $1 \mathrm{~m}$ width and $20 \mathrm{~m}$ long and has $5 \times 5 \mathrm{~cm}$ square. Based on the previous studies, the abundance and number of species are higher in the seagrasses the leaves of which are between 20 and $40 \mathrm{~cm}$ (Mattila et al., 1999). Therefore, we kept the leave length as 30 $\mathrm{cm}$. Then AS model was placed into the 2 nd Station (Figure 2) on 8 April 2016 and into the 3rd station on 27 May 2016. The models were fixed on the ground by using T-shaped rods.

Sampling at the stations was done weekly at the same time. Sampling in S1 and S2 started on April 28, and S3 on June 17, 2016 and ended on August 11, 2016.

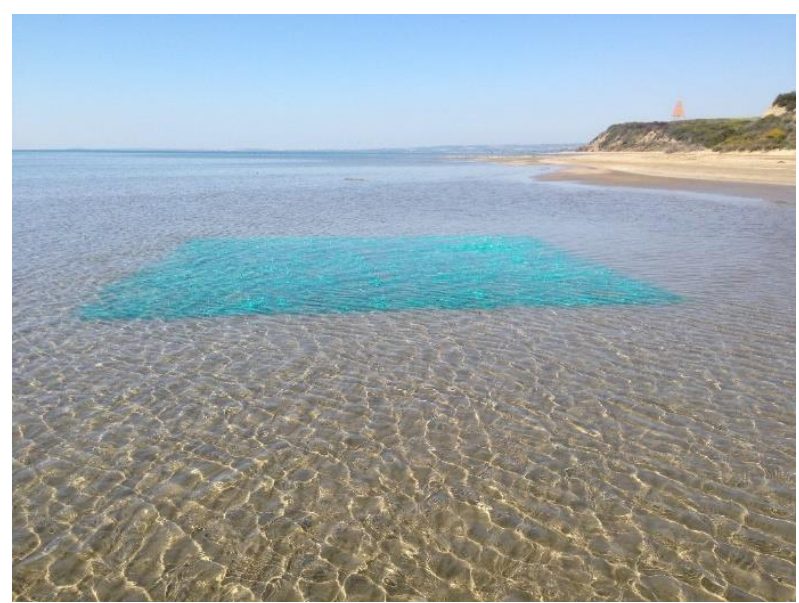

Figure 2. The AS area created for Station 2

The specimens were identified at the lowest possible taxonomic level using the following references Whitehead et al. (1986), Golani et al. (2006), Turan (2007) and Froese and Pauly (2016). The number of individuals were recorded for each species. After the procedures, alive specimens were released back into the sea and the ones those were already dead were fixed in a $10 \%$ formaldehyde solution for further investigations.

The change of total abundance and total number of species based on day of sampling, habitat type and station were analyzed by using generalized additive models. The models were fitted following the protocols suggested by Zuur et al. (2009) using MASS library (Venables and Ripley, 2002) in R environment (Team, 2017). The changes of species composition were analyzed with Constrained Analyze of Principle Coordinates (CAP) using vegan and Biodiversity $R$ libraries of $\mathrm{R}$ environment (Kindt and Coe, 2005; Oksanen et al., 2013)

\section{RESULTS}

A total of 29 different species of juvenile fish were detected in the samplings in NS areas. The most dominant species was found to be Atherina boyeri (68.92\%) followed by Siganus rivulatus (16.46\%), Gobius niger (6.36\%) and Diplodus sargus (4.18\%) (Figure 3.). 


\section{Natural Seagrass}

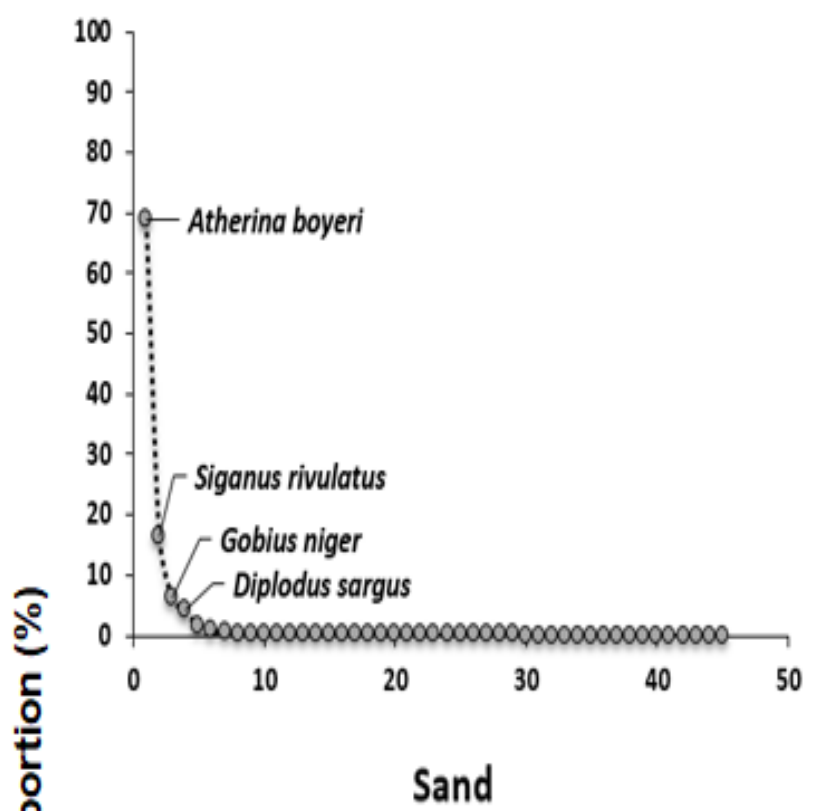

Artificial Seagrass

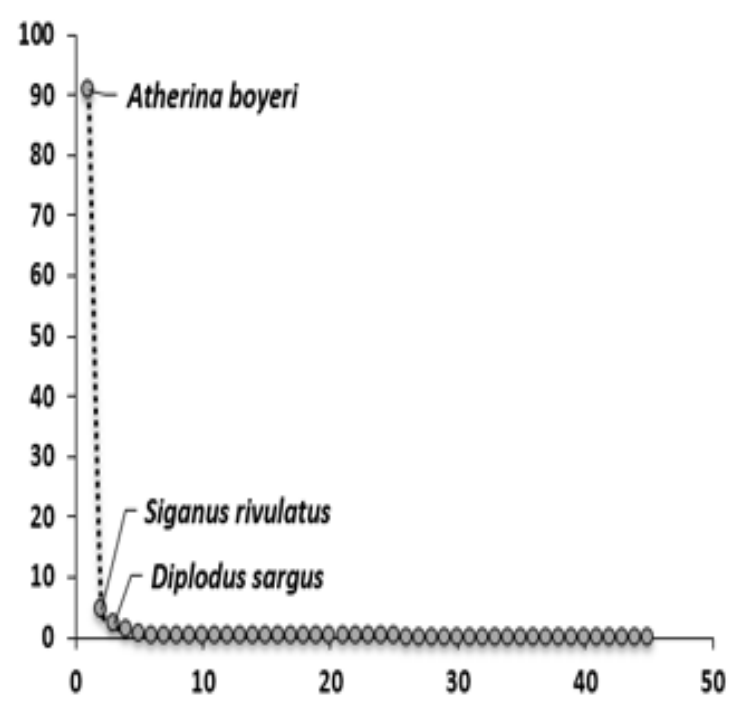

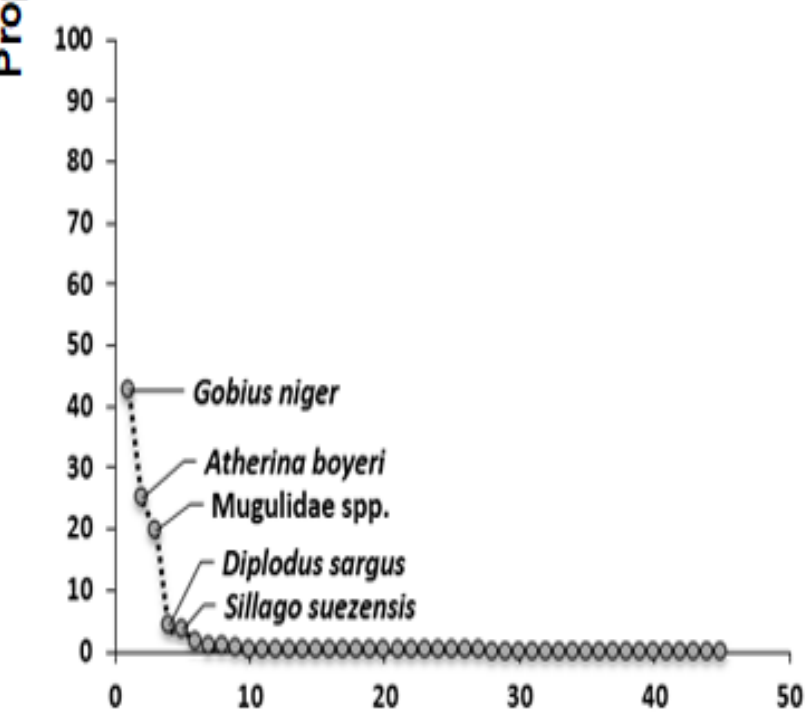

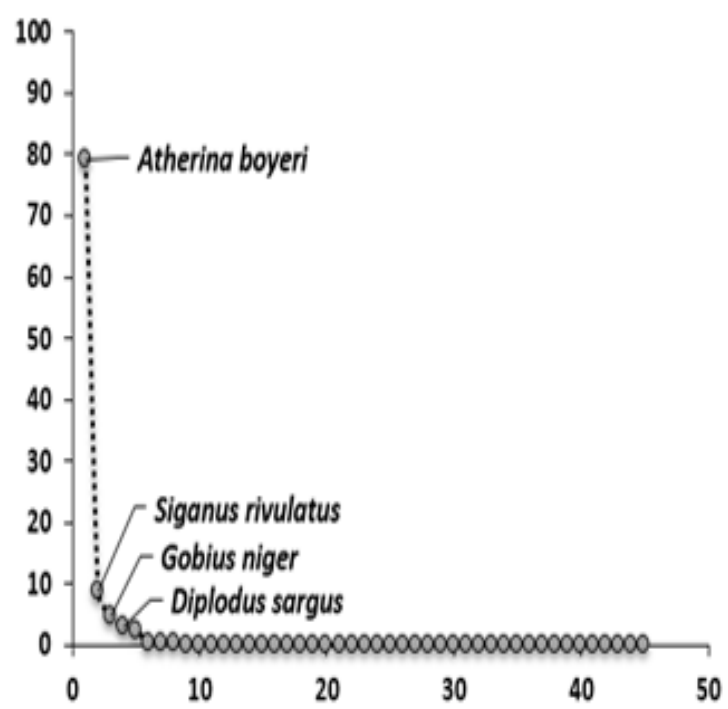

\section{Species Rank}

Figure 3. Rank abundance curves of NS, AS and Sand habitats, and overall study area

Results of GAMs revealed that overall average fish abundance and number of species were similar in AS and NS habitats and the both were significantly lower in $S$ habitats (Table 2, Table 3, Figure 4, Figure 5).

Fish abundance did not reveal any significant trends along time in NS, and S habitats of S1 and S2. On the other hand, two contrasting patterns were appeared in AS. In S2, fish abundance revealed a clear increment after 80th days of experiments, whereas it monotonously decreased in S3. In stations, the number of species remained similar or decreased along the experiments in S and NS habitats, respectively. Change in AS habitat of S2 was not significant whereas GAM revealed a significantly fluctuating pattern in AS habitat of S3. 
Table 2. Estimated regression parameters and approximate significance of smooth terms of negative binomial (NB) generalized additive model for total fish abundance

\begin{tabular}{|c|c|c|c|c|}
\hline \multicolumn{5}{|c|}{ Abundance $e_{\mathrm{jk}} \sim N B\left(\mu_{\mathrm{ijk}}\right) ; \ln \left(\mu_{\mathrm{ijk}}+1\right)=\operatorname{lntercept}+\mathrm{H}_{\mathrm{i}}+\mathrm{s}\left(\mathrm{DoY}_{\mathrm{k}}: \mathrm{H}_{\mathrm{i}}: \mathrm{S}_{\mathrm{k}}\right)+\varepsilon_{\mathrm{ijk}}$} \\
\hline \multicolumn{5}{|c|}{ Parametric coefficients: } \\
\hline & Estimate & Std. Error & $\mathbf{z}$ value & $p$ value \\
\hline Intercept & 6.030 & 0.183 & 32.918 & $<0.001$ \\
\hline Habitat NS & 0.101 & 0.272 & 0.371 & 0.711 \\
\hline Habitat S & -1.851 & 0.234 & -7.901 & $<0.001$ \\
\hline \multicolumn{5}{|c|}{ Approximate significance of smooth terms: } \\
\hline & edf & Ref.df & Chi.sq & $\mathrm{p}$-value \\
\hline$s(D o Y): S_{1}, H_{N S}$ & 1.000 & 1.000 & 0.701 & 0.403 \\
\hline $\mathrm{s}(\mathrm{DoY}): \mathrm{S}_{1}, \mathrm{H}_{\mathrm{s}}$ & 2.642 & 3.282 & 4.775 & 0.211 \\
\hline $\mathbf{s}(\mathrm{DoY}): \mathrm{S}_{2}, \mathrm{H}_{\mathrm{AS}}$ & 6.893 & 7.978 & 71.813 & $<0.001$ \\
\hline $\mathrm{s}(\mathrm{DoY}): \mathrm{S}_{2}, \mathrm{H}_{\mathrm{s}}$ & 3.687 & 4.550 & 9.464 & 0.088 \\
\hline $\mathbf{s}(\mathrm{DoY}): \mathrm{S}_{3}, \mathrm{H}_{\mathrm{AS}}$ & 1.000 & 1.000 & 29.742 & $<0.001$ \\
\hline $\mathrm{s}(\mathrm{DoY}): \mathrm{S}_{3}, \mathrm{H}_{\mathrm{NS}}$ & 2.463 & 3.010 & 7.641 & 0.054 \\
\hline $\mathbf{s}(\mathrm{DoY}): \mathrm{S}_{3}, \mathrm{Hs}$ & 2.237 & 2.739 & 11.270 & 0.008 \\
\hline
\end{tabular}

$R^{2}($ adj $)=0.798$, Deviance explained $=81.6 \%, n=91$

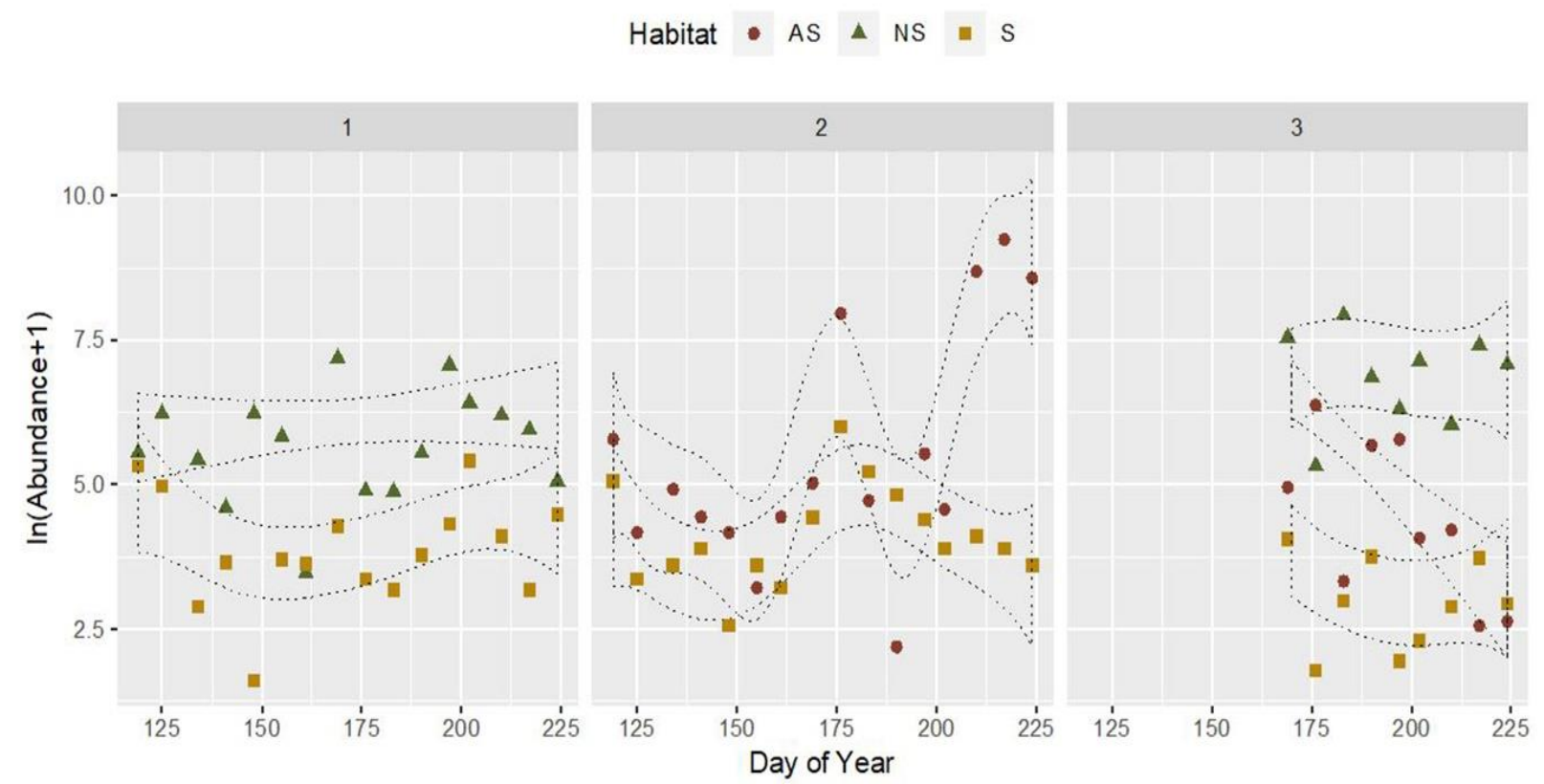

Figure 4. Fit of the negative binomial GAM in Table 2 for the total abundance 
Table 3. Estimated regression parameters and approximate significance of smooth terms of quasi-Poisson (QP) generalized additive model for the richness of fish species

\begin{tabular}{|c|c|c|c|c|}
\hline \multicolumn{5}{|c|}{ 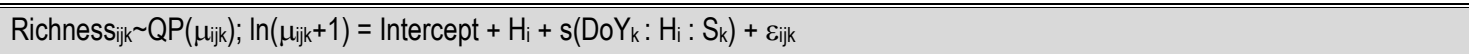 } \\
\hline \multicolumn{5}{|c|}{ Parametric coefficients: } \\
\hline & Estimate & Std. Error & $z$ value & $\mathrm{p}$ value \\
\hline Intercept & 1.443 & 0.099 & 14.599 & $<0.001$ \\
\hline Habitat NS & 0.198 & 0.134 & 1.477 & 0.144 \\
\hline Habitat S & -0.435 & 0.132 & -3.308 & 0.001 \\
\hline \multicolumn{5}{|c|}{ Approximate significance of smooth terms: } \\
\hline & edf & Ref.df & Chi.sq & p-value \\
\hline $\mathbf{s}(\mathrm{DoY}): \mathrm{S}_{1}, \mathrm{H}_{\mathrm{NS}}$ & 1.000 & 1.000 & 5.743 & 0.019 \\
\hline$s(D o Y): s_{1}, H_{s}$ & 1.242 & 1.444 & 3.058 & 0.105 \\
\hline $\mathrm{s}(\mathrm{DoY}): \mathrm{S}_{2}, \mathrm{H}_{\mathrm{AS}}$ & 1.000 & 1.001 & 3.412 & 0.069 \\
\hline $\mathrm{s}(\mathrm{DoY}): \mathrm{S}_{2}, \mathrm{H}_{\mathrm{s}}$ & 1.000 & 1.000 & 0.163 & 0.687 \\
\hline $\mathbf{s}(\mathrm{DoY}): \mathrm{S}_{3}, \mathrm{H}_{\mathrm{AS}}$ & 5.382 & 5.897 & 2.653 & 0.017 \\
\hline $\mathbf{s}(\mathrm{DoY}): \mathrm{S}_{3}, \mathrm{H}_{\mathrm{NS}}$ & 2.966 & 3.581 & 6.993 & $<0.001$ \\
\hline$s(D \circ Y): S_{3}, H_{s}$ & 2.512 & 3.055 & 4.165 & 0.008 \\
\hline
\end{tabular}

$R^{2}($ adj $)=0.605, \quad$ Deviance explained $=61.8 \%, n=91$

Habitat $\bullet$ AS $\Delta$ NS $=S$

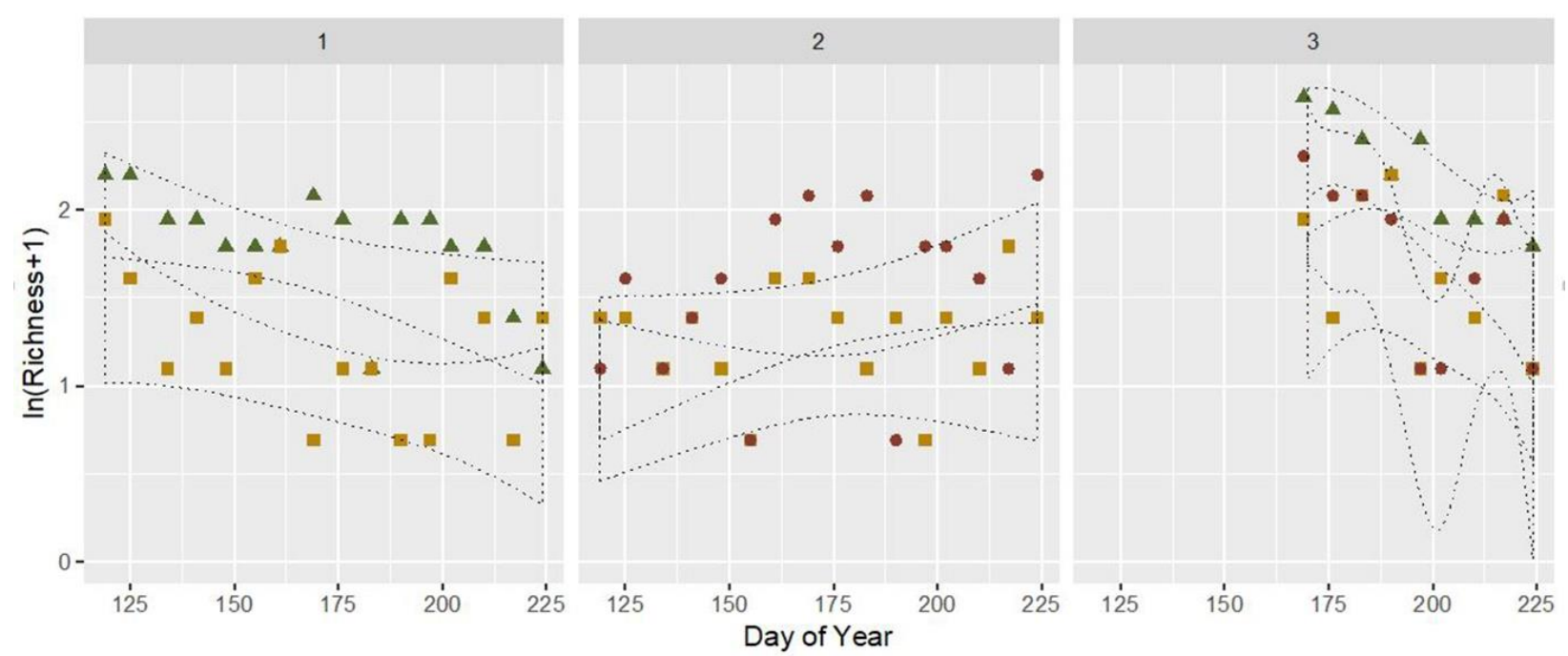

Figure 5. Fit of the quasi-Poisson GAM in Table 3 for the total richness

CAP and SimProf results revealed that the species composition was significantly changed among habitats and stations (Table 4).
Whereas artificial and NS possessed a similar composition, $S$ habitats of all three stations were different than each other (Figure 6). 
Table 4. Eigenvalues and its proportion in total and constrained inertia of first two constrained analysis of principle coordinates (CAP) axes, and the results of marginal permutation test for CAP

\begin{tabular}{lllll}
\hline & CAP1 & CAP2 & Constrained Total & Total \\
\hline Eigenvalue & 0.328 & 0.216 & 0.686 & 0.759 \\
Proportion in Total Inertia & 0.432 & 0.284 & 0.903 & 1.000 \\
Proportion in Constrained Inertia & 0.478 & 0.314 & 1.000 & - \\
Source of Variation & df & SS & F & p value \\
Habitat & $\mathbf{2}$ & $\mathbf{0 . 2 6 3}$ & $\mathbf{2 . 6 6 4}$ & $\mathbf{0 . 0 4 1}$ \\
Station & $\mathbf{2}$ & $\mathbf{0 . 3 9 4}$ & $\mathbf{3 . 9 8 8}$ & $\mathbf{0 . 0 0 2}$ \\
Residual & 2 & 0.099 & &
\end{tabular}

n of permutations $=999$

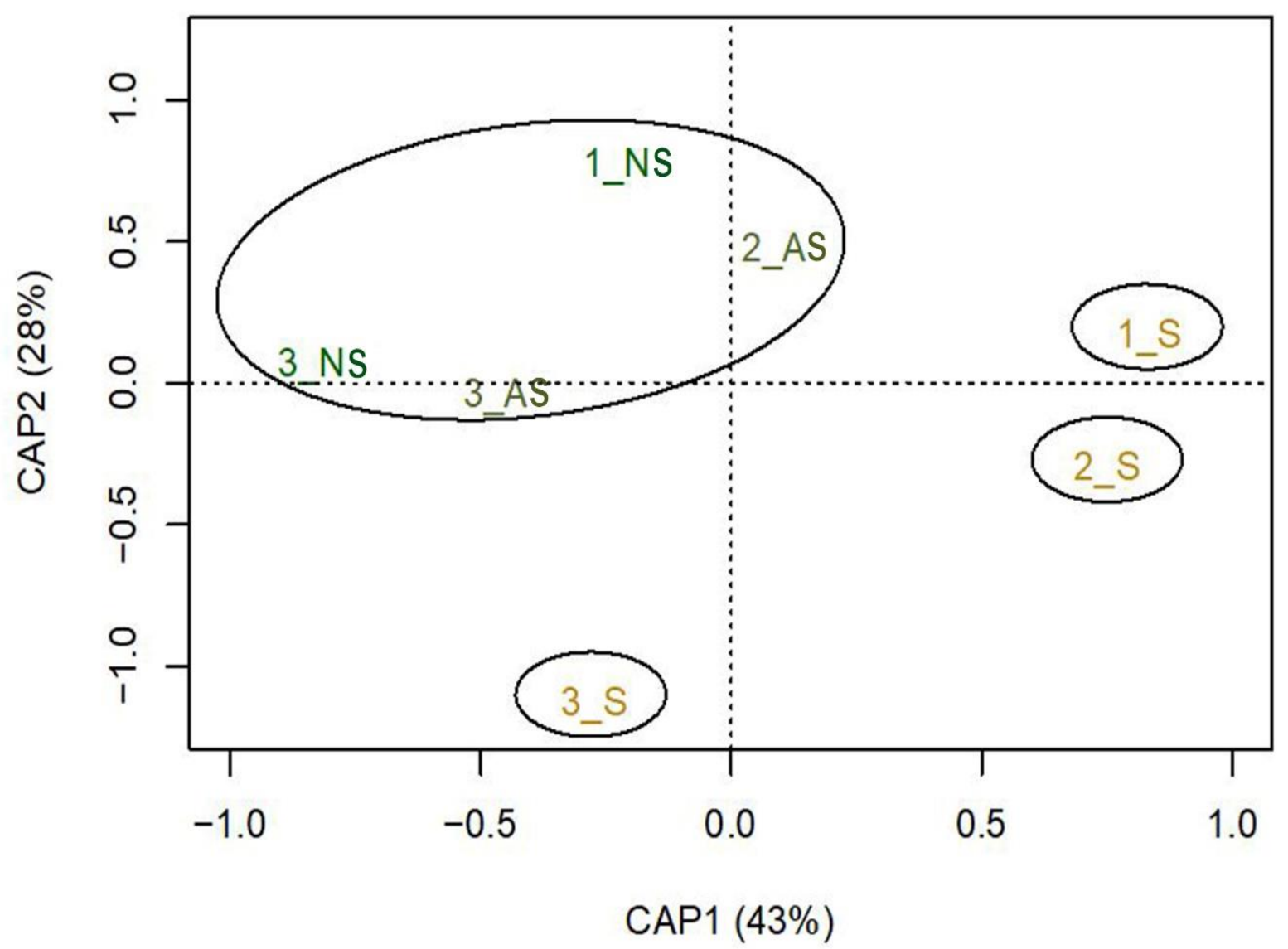

Figure 6. Results of constrained analysis of principle coordinates (CAP) ordination. Ellipses show statistically significant clusters at $95 \%$ confidence level based on a similarity profiling (SimProf) analyze

\section{DISCUSSION AND CONCLUSION}

In context of our study, a total of 45 species were detected between April and August in the Northeast
Mediterranean (Table 5). In the same area also Başusta et al. (2002) reported 33 species. These numbers are not close to each other. Because of our study is in shallow water while the other study is at depths of up to 30 meters. 
Artificial seagrass experiments in the Northeast Mediterranean

Table 5. Abundance of fish species (individual per $100 \mathrm{~m}^{2}$ ) detected in context of the study (NS: Natural Seagrass, AS: Artificial Seagrass, S: Sand)

\begin{tabular}{|c|c|c|c|c|c|c|c|}
\hline FAMILY / SPECIES & $\begin{array}{l}\text { Station I } \\
\text { NS }\end{array}$ & $\mathrm{s}$ & $\begin{array}{l}\text { Station II } \\
\text { AS }\end{array}$ & $\mathrm{s}$ & $\begin{array}{l}\text { Station III } \\
\text { NS }\end{array}$ & AS & $\mathbf{s}$ \\
\hline \multicolumn{8}{|l|}{ Atherinidae } \\
\hline Atherina boyeri & 2609 & 103 & 24028 & 460 & 9122 & 653 & 57 \\
\hline Atherinomorus lacunosus & 2 & 1 & 4 & 4 & - & - & - \\
\hline \multicolumn{8}{|l|}{ Bothidae } \\
\hline Arnoglossus laterna & - & - & - & - & - & - & 2 \\
\hline Arnoglossus spp. & - & - & - & - & 1 & - & - \\
\hline \multicolumn{8}{|l|}{ Blenniidae } \\
\hline Blenniidae spp. & - & - & - & - & 1 & - & - \\
\hline Parablennius gattorugine & - & - & - & - & 1 & - & - \\
\hline Parablennius sanguinolentus & 4 & - & 28 & - & 4 & - & - \\
\hline \multicolumn{8}{|l|}{ Callionymidae } \\
\hline Callionymus filamentosus & - & - & - & - & - & 1 & 2 \\
\hline \multicolumn{8}{|l|}{ Carangidae } \\
\hline Seriola dumerili & - & - & 4 & 4 & - & - & - \\
\hline Trachinotus ovatus & - & - & 12 & 4 & - & - & - \\
\hline \multicolumn{8}{|l|}{ Dussumieriidae } \\
\hline Dussumieria elopsoides & - & - & 4 & - & - & - & - \\
\hline \multicolumn{8}{|l|}{ Engraulidae } \\
\hline Engraulis encrasicolus & - & - & - & 4 & - & - & - \\
\hline \multicolumn{8}{|l|}{ Fistulariidae } \\
\hline Fistularia commersonii & - & - & - & - & - & - & 1 \\
\hline \multicolumn{8}{|l|}{ Gobidae } \\
\hline Gobiidae spp. & 1 & - & 4 & - & - & - & - \\
\hline Gobius niger & 1064 & 456 & 132 & 528 & 19 & 7 & 71 \\
\hline \multicolumn{8}{|l|}{ Haemulidae } \\
\hline Pomadasys stridens & - & - & - & - & 8 & - & - \\
\hline Leiognathidae & & & & & & & \\
\hline Equulites klunzingeri & - & - & - & - & 28 & 26 & 3 \\
\hline Monacanthidae & & & & & & & \\
\hline Stephanolepis diaspros & - & - & - & - & 3 & - & - \\
\hline Moronidae & & & & & & & \\
\hline Dicentrarchus labrax & 25 & - & - & - & - & - & - \\
\hline Mugilidae & & & & & & & \\
\hline Mugilidae spp. & 257 & 326 & 316 & 160 & 22 & 21 & - \\
\hline Mullidae & & & & & & & \\
\hline Mullus barbatus & 8 & - & - & - & 1 & 16 & 2 \\
\hline Mullus surmuletus & 1 & - & - & - & 3 & - & - \\
\hline Upeneus pori & - & - & - & - & - & 2 & 9 \\
\hline Serranidae & & & & & & & \\
\hline Mycteroperca rubra & - & - & - & - & 31 & 1 & 3 \\
\hline Serranidae spp. & - & - & - & - & - & - & 1 \\
\hline Siganidae & & & & & & & \\
\hline Siganus luridus & 6 & - & 24 & - & 1 & 4 & - \\
\hline Siganus rivulatus & 1284 & - & 564 & 12 & 1518 & 692 & 28 \\
\hline Sillaginidae & & & & & & & \\
\hline Sillago suezensis & - & 22 & 36 & 64 & - & 1 & 1 \\
\hline Soleidae & & & & & & & \\
\hline Buglossidium luteum & 1 & 2 & 20 & - & 1 & 3 & - \\
\hline Microchirus ocellatus & - & - & 4 & - & - & - & - \\
\hline Pegusa lascaris & - & - & - & 4 & 1 & - & 2 \\
\hline Solea solea & - & 3 & - & - & - & - & - \\
\hline Sparidae & & & & & & & \\
\hline Diplodus sargus & 679 & 10 & 492 & 84 & 33 & 68 & 7 \\
\hline Lithognathus mormyrus & - & - & 4 & - & - & - & - \\
\hline Pagellus erythrinus & 3 & 1 & - & - & - & - & - \\
\hline Sparidae spp. & 2 & - & - & - & - & - & 1 \\
\hline Sparus aurata & 88 & 13 & 4 & 4 & 5 & 2 & 2 \\
\hline Sphyraenidae & & & & & & & \\
\hline Sphyraena chrysotaenia & - & - & - & - & 4 & - & - \\
\hline Sphyraena sphyraena & - & - & - & - & - & 1 & 2 \\
\hline Syngnathidae & & & & & & & \\
\hline Nerophis ophidion & - & - & - & - & 5 & - & - \\
\hline Syngnathus abaster & - & - & - & - & - & 1 & - \\
\hline Syngnathus phlegon & - & - & - & - & 1 & - & - \\
\hline Terapontidae & & & & & & & \\
\hline Pelates quadrilineatus & 145 & - & - & - & 9 & - & - \\
\hline Trachinidae & & & & & & & \\
\hline Echiichthys vipera & 8 & - & 4 & 12 & 12 & 2 & 6 \\
\hline Trachinus araneus & - & - & - & - & - & - & 3 \\
\hline
\end{tabular}


Results of generalized additive models and similarity profiling analysis revealed that there was not statistically significant difference of the species composition, number of species and total abundance between AS and NS, whereas all three parameters were significantly different in $S$ habitats. This situation demonstrated that the AS could simulate the NS. Similarly, Guidetti (2000) reported that seagrass areas are more preferred than sand areas. Factors such as nutrition, predators, the abundance of food come into play as reasons for fish to prefer seagrass as their habitat (Heck et al., 1997).

As larval stage, juvenile fish assemblages are also temporary associations (Miller, 2002), depends on the seasonality of spawning and settlement processes (Ak, 2004; Banbul, 2014). Accordingly, we detected the highest richness in April when the highest rate of ichthyoplankton richness and abundance were reported in the study area (Mavruk et al., 2018). In accordance with ichthyoplankton samplings performed by Mavruk et al. (2018) our richness were contentiously decreased in all stations and habitats over the periods of experiments depending on the decreasing spawning activity in the study area.

The habitats for adult and juvenile fish was ranked by Beck et al. (2001) from most to least efficient as seagrass, swamp, muddy areas, sand habitats in this order. The areas with seagrass were preferred by fish to areas without plants such as sand grounds and loams (Ferrell and Bell, 1991; Mattila et al., 1999; Pihl et al., 2006). Similarly, in our study, NS and AS have higher fish abundance values than sand habitats. The fish abundance and richness were relatively stable in NS and S habitats, as seen in the sampling. Whereas, AS revealed a fluctuating pattern in these two parameters. On the other hand, species compositions of $S$ habitats were more variable. This may be due to the insufficient amount of sampling.

Different species preferred different kinds of habitats (Mattila et al., 1999). Atherina boyeri, which are carnivorous, and which represent the $79.31 \%$ of the total abundance of fish, were the predominant species in this study. Considering the fact that $31.67 \%$ of this species was observed in areas with

\section{REFERENCES}

Ak, Y. (2004). Distribution and abundance of the pelagic eggs and larvae of some Teleostean fishes in living off Erdemli, Mersin. Ege University Institutes of Natural and Applied Science, Faculty of Fisheries, PhD thesis.

Andrady, A.L. (2011). Microplastics in the marine environment. Marine Pollution Bulletin, 62(8), 1596-1605. DOI:10.1016/j.marpolbul.2011.05.030

Andrady, A.L. \& Neal, M.A. (2009). Applications and societal benefits of plastics. Philosophical Transactions of the Royal Society of London B. Biological Sciences, 364(1526), 1977-1984. DOI: 10.1098/rstb.2008.0304

Avşar, D., Çiçek, E. \& Akamca, E. (1999). Yumurtalık koyu (ADANA) kıyısal zonunun yaz dönemi yavru kemikli balık faunası. 10th National Fisheries Symposium, Adana, 420-429.

Aysel, V., Erduğan, H. \& Okudan, E. (2006). Marine Algae and Seagrasses of Adana (Mediterranean, Turkey). Journal of the Black Sea / Mediterranean Environment, 12, $35-57$. seagrass, $66.64 \%$ in areas with AS, $1.67 \%$ in S habitats, it can be said to be a resident species of NS and AS.

High-density and low-density polyethylene (PE), polypropylene (PP), polyvinyl chloride (PVC), polyester (PS), polyvinyl terephthalate (PET) make up $90 \%$ of the world production as the most commonly used plastics (Andrady and Neal, 2009). Therefore, it is known that most of the substances polluting the coastal and marine environments are composed of these materials (Andrady, 2011; Engler, 2012). Increasing sea pollution along with microplastics and marine debris which are discussed in many researches pose a threat to the ecosystem (Gündoğdu and Çevik, 2017; Gündoğdu et al., 2017). Nowadays, it is widely accepted that plastic pollution affects numerous marine species ranging from zooplanktons to whales (Andrady, 2011; Cole et al., 2013; Cole et al., 2011). Plastic wastes harm marine species as their gills can be clogged by plastics and they can get tangled in them and/or swallow them (Gregory, 2009; Li et al., 2016). Therefore, the use of plastic (polypropylene) as a material in AS is controversial. The general consensus is that preferring natural fibers when choosing materials is more of an eco-friendly approach and is predicted to prevent possible controversies.

Seagrass habitats have important roles in the coastal ecosystems. Therefore, they are extremely vulnerable to various stressors and declining all over the world. In this study, AS was tested as an alternative to the declining seagrass. Our study revealed that the abundance of fish is higher in the NS and AS in comparison with S habitats. This study, conducted in the Northeast Mediterranean, shows that AS habitats effect the distribution of juvenile fish.

\section{ACKNOWLEDGEMENTS}

This work is a part of MSc thesis named "Effect on the juvenile fish distribution of artificial seagrass", It was supported by the Scientific Research Project Unit of Çukurova University (FYL-2016-5507).

Banbul, B. (2014). Distribution of ichthyoplankton in relation to ecological conditions in the epipelagial of the Gulf of Antalya. Ph.D. Thesis, Akdeniz University. (in Turkish). 472.

Başusta, N., Kumlu, M., Gökçe, M. A. \& Göçer, M. (2002). Yumurtalık Koyu'nda Dip Trolü ile Yakalanan Türlerin Mevsimsel Değişimi ve Verimlilik Indeksi. Su Ürünleri Dergisi, 19(1), 29-34.

Beck, M.W., Heck, K.L., Able, K.W., Childers, D.L., Eggleston, D.B., Gillanders, B.M., Halpern, B., Hays, C.G., Hoshino, K., Minello, T.J., Orth, R.J., Sheridan, P. F. \& Weinstein, M. R. (2001). The identification, conservation, and management of estuarine and marine nurseries for fish and invertebrates. Bioscience, 51(8), 633-641. DOI:10.1641/0006-3568(2001)051[0633:Ticamo]2.0.Co;2

Becker, N. \& Choresh, Y. (2006). Economic aspects of Marine Protected Areas (MPAs). 131. Retrieved from http://www.racspa.org/sites/default/files/doc_spa/ev2006.pdf 
Boudouresque, C., Gravez, V., Meinesz, A., Molenaar, H., Pergent, G. \& Vitiello, P. (1994). L'herbier à Posidonia oceanica en Méditerranée: protection légale et gestion. Paper presented at the Actes du colloque scientifique OKEANOS, Maison de l'Environnement de Montpellier publ., France.

Cole, M., Lindeque, P., Halsband, C., \& Galloway, T. S. (2011). Microplastics as contaminants in the marine environment: a review. Marine Pollution Bulletin, 62(12), 2588-2597. DOI:10.1016/j.marpolbul.2011.09.025

Cole, M., Lindeque, P., Fileman, E., Halsband, C., Goodhead, R., Moger, J. \& Galloway, T. S. (2013). Microplastic ingestion by zooplankton. Environmental science technology, 47(12), 6646-6655. DOI:10.1021/es400663f

Deegan, L.A., Wright, A., Ayvazian, S.G., Finn, J.T., Golden, H., Merson, R.R. \& Harrison, J. (2002). Nitrogen loading alters seagrass ecosystem structure and support of higher trophic levels. Aquatic ConservationMarine and Freshwater Ecosystems, 12(2), 193-212. DOI: $10.1002 /$ aqc. 490

Demirci, G.G. \& Karakan, İ. (2006). Sinop Kıyılarında ( Orta Karadeniz ) Deniz Çayırlarının Dağılımı. Fırat Üniv. Fen ve Müh. Bil. Dergisi, 18(3), 331-337.

Engler, R.E. (2012). The complex interaction between marine debris and toxic chemicals in the ocean. Environmental Science \& Technology, 46(22), 12302-12315. DOI:10.1021/es3027105

Ferrell, D.J. \& Bell, J.D. (1991). Differences among assemblages of fish associated with Zostera capricorni and bare sand over a large spatial scale. Marine Ecology Progress Series, 72(1-2), 15-24. DOI:10.3354/meps072015

Froese, R. \& Pauly, D. (2016). Fishbase: World Wide Web electronic publication, version (10/2016).

Golani, D., Oztürk, B. \& Başusta, N. (2006). Fishes of The Eastern Mediterranean. Turkish Marine Research Foundation, Istanbul., 24.

Gregory, M.R. (2009). Environmental implications of plastic debris in marine settings-entanglement, ingestion, smothering, hangers-on, hitch-hiking and alien invasions. Philosophical Transactions of the Royal Society B: Biological Sciences, 364(1526), 2013-2025. DOI:10.1098/rstb.2008.0265

Guidetti, P. (2000). Differences among fish assemblages associated with nearshore Posidonia oceanica seagrass beds, rocky-algal reefs and unvegetated sand habitats in the Adriatic Sea. Estuarine, Coastal and Shelf Science, 50(4), 515-529. DOI:10.1006/ecss.1999.0584

Gullstrom, M., Bodin, M., Nilsson, P.G. \& Ohman, M.C. (2008). Seagrass structural complexity and landscape configuration as determinants of tropical fish assemblage composition. Marine Ecology Progress Series, 363, 241-255. DOI:10.3354/meps07427

Gündoğdu, S. \& Çevik, C. (2017). Micro-and mesoplastics in Northeast Levantine coast of Turkey: The preliminary results from surface samples. Marine Pollution Bulletin, 118(1-2), 341-347. DOI:10.1016/j.marpolbul.2017.03.002

Gündoğdu, S., Çevik, C. \& Karaca, S. (2017). Fouling assemblage of benthic plastic debris collected from Mersin Bay, NE Levantine coast of Turkey. Marine Pollution Bulletin, 124(1), 147-154. DOI:10.1016/j.marpolbul.2017.07.023

Heck, K. L., Nadeau, D. A. \& Thomas, R. (1997). The Nursery Role of Seagrass Beds. Gulf of Mexico Science, 15, 50-54. DOI:10.18785/goms.1501.08

Hemminga, M.A. \& Duarte, C.M. (2000). Seagrass ecology. Cambridge, UK ; New York, NY: Cambridge University Press. DOI: $10.1017 /$ СBO 9780511525551

Irving, A.D., Tanner, J.E., Seddon, S., Miller, D., Collings, G.J., Wear, R.J., Hoare, S. L. \& Theil, M. J. (2010). Testing alternate ecological approaches to seagrass rehabilitation: links to life-history traits. Journal of Applied Ecology, 47(5), 1119-1127.

DOI:10.1111/j.1365-2664.2010.01852.x

Jenkins, G.P., May, H.M.A., Wheatley, M.J. \& Holloway, M.G. (1997). Comparison of fish assemblages associated with seagrass and adjacent unvegetated habitats of Port Phillip Bay and Corner Inlet, Victoria,
Australia, with emphasis on commercial species. Estuarine Coastal and Shelf Science, 44(5), 569-588. DOI:10.1006/ecss.1996.0131

Kindt, R., \& Coe, R. (2005). Tree diversity analysis: a manual and software for common statistical methods for ecological and biodiversity studies. World Agroforestry Centre. DOI:10.13140/RG.2.1.1993.7684

Kuo, J. \& Den Hartog, C. (2007). Seagrass morphology, anatomy, and ultrastructure. In Seagrasses: biology, ecologyand conservation (pp. 5187): Springer.DOI:10.1007/978-1-4020-2983-7_3

Lee, H.B. \& Low, J. (1991). The enhancement of fish community in the Singapore River through the use of artificial seagrass (Vol. ICLARM Conference Proceedings 25): Urban Coastal Area Management: The Experience of Singaporea- At: Int Center Living Aquatic Resources Management, Manila.

Li, H.-X., Orihuela, B., Zhu, M. \& Rittschof, D. (2016). Recyclable plastics as substrata for settlement and growth of bryozoans Bugula neritina and barnacles Amphibalanus amphitrite. Environmental pollution, 218, 973980. DOI:10.1016/j.envpol.2016.08.047

Mattila, J., Chaplin, G., Eilers, M.R., Heck, K. L., O'Neal, J.P. \& Valentine, J. F. (1999). Spatial and diurnal distribution of invertebrate and fish fauna of a Zostera marina bed and nearby unvegetated sediments in Damariscotta River, Maine (USA). Journal of Sea Research, 41(4), 321-332. DOI:10.1016/S1385-1101(99)00006-4

Mavruk, S., Bengil, F., Yüksek, A., Özyurt, C.E., Kiyağa, V.B. \& Avşar, D. (2018). Intra-annual patterns of coastal larval fish assemblages along environmental gradients in the northeastern Mediterranean. Fisheries Oceanography, 27(3), 232-245. DOI:10.1111/fog.12248

Meinesz, A., Caye, G., Loques, F. \& Molenaar, H. (1991). Restoration of damaged areas with transplantation of seaweeds and seagrasses in the Mediterranean: review and perspectives. Oebalia. Taranto, 17.

Miller, T. J. (2002). Assemblages, communities, and species interactions. In L.E. Fuimann \& R.G. Werner (Eds.), Fishery Science. The unique contributions of early life stages. Blackwell Publishing, Oxford, 183-205.

Oksanen, J., Blanchet, F.G., Kindt, R., Legendre, P., Minchin, P. \& O'Hara, R. B. (2013). Vegan: Community Ecology, Package. R Package Version 2.21.

Orth, R.J., Heck, K.L. \& Vanmontfrans, J. (1984). Faunal Communities in Seagrass Beds - a Review of the Influence of Plant Structure and Prey Characteristics on Predator Prey Relationships. Estuaries, 7(4a), 339350. DOI:10.2307/1351618

Orth, R. J. (1992). A Perspective on Plant-Animal Interactions in Seagrasses Physical and Biological Determinants Influencing Plant and Animal Abundance. Plant-Animal Interactions in the Marine Benthos, 46, 147164.

Orth, R.J., Carruthers, T.J.B., Dennison, W.C., Duarte, C.M., Fourqurean, J.W., Heck, K.L., Hughes, A.R., Kendrick, G.A., Kenworthy, W.J., Olyarnik, S., Short, F.T., Waycott, M. \& Williams, S. L. (2006). A global crisis for seagrass ecosystems. Bioscience, 56(12), 987-996. DOI:10.1641/0006-3568(2006)56[987:Agcfse]2.0.Co;2

Pihl, L., Baden, S., Kautsky, N., Ronnback, P., Soderqvist, T., Troell, M. \& Wennhage, H. (2006). Shift in fish assemblage structure due to loss of seagrass Zostera marina habitats in Sweden. Estuarine Coastal and Shelf Science, 67(1-2), 123-132. DOI:10.1016/j.ecss.2005.10.016

Pollard, D.A. (1984). A Review of Ecological-studies on seagrass fish communities, with particular reference to recent studies in Australia. Aquatic Botany, 18(1-2), 3-42. DOI:10.1016/0304-3770(84)90079-2

Protocol, S. (1995). Protocol concerning specially protected areas and biological diversity in the Mediterranean. UNEP. Barcelona, Spain, 9-10.

Saad, S., Jalal, K. C. A., Kamaruzzam, Y., Mohammad Noor, N., Chit Dah, T. \& John, A. (2011). Artificial Seagrass: A Habitat for Marine Fishes. Journal of Fisheries and Aquatic Science, 6, 85-92. DOI:10.3923/ffas.2011.85.92

Spalding, M., Taylor, M., Ravilious, C., Short, F. \& Green, E. (2003). Global overview. The Distribution and Status of Seagrasses. In World Atlas of Seagrasses. 
Team, R.C. (2017). R: A language and environment for statistical computing. Vienna, Austria: R Foundation for Statistical Computing; 2017. In: ISBN3900051-07-0 https://www. R-project. org.

Turan, C. (2007). Türkiye Kemikli Deniz Balıkları Atlası ve Sistematiği. Adana: NOBEL KITABEVI.

Tuya, F., Haroun, R. \& Espino, F. (2014). Economic assessment of ecosystem services: Monetary value of seagrass meadows for coastal fisheries. Ocean \& Coastal Management, 96, 181-187. DOI:10.1016/j.ocecoaman.2014.04.032

Upston, J. \& Booth, D.J. (2003). Settlement and density of juvenile fish assemblages in natural, Zostera capricorni (Zosteraceae) and artificial seagrass beds. Environmental Biology of Fishes, 66(1), 91-97. DOI:10.1023/A:1023246427710
Venables, W.N. \& Ripley, B.D. (2002). Modern applied statistics with S. Statistics and computing, 4th, 1-495. DOI:10.1007/b97626

Waycott, M., Procaccini, G., Les, D.H. \& Reusch, T.B.H. (2006). Seagrass Evolution, Ecology and Conservation: A Genetic Perspective. In Seagrasses: Biology, Ecologyand Conservation (pp. 25-50). Dordrecht: Springer Netherlands. DOI:10.1007/978-1-4020-2983-7_2

Whitehead, P.J.P., Bauchot, M. L., Hureau, J. C., Nielsen, J. \& Tortonese, E. (1986). Fishes of the North-Eastern Atlantic and the Mediterranean. v.2, 517-1007. DOI:10.2307/1444931

Zuur, A., leno, E.N., Walker, N., Saveliev, A. \& Smith, G.M. (2009). Mixed Effects Models and Extensions in Ecology With R. Journal of Statistical Software, 32, 1-574. DOI:10.1007/978-0-387-87458-6_1 